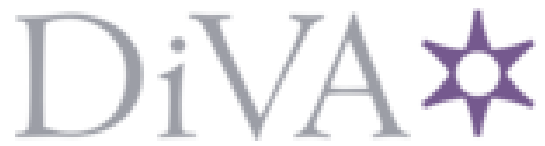

http://www.diva-portal.org

\title{
Postprint
}

This is the accepted version of a paper published in . This paper has been peer-reviewed but does not include the final publisher proof-corrections or journal pagination.

Citation for the original published paper (version of record):

Kaun, A., Dencik, L. (2020)

Datafication and the Welfare State: An Introduction

Global Perspectives, 1(1): 12912

https://doi.org/10.1525/gp.2020.12912

Access to the published version may require subscription.

N.B. When citing this work, cite the original published paper.

Published as Lina Dencik, Anne Kaun; Datafication and the Welfare State. Global Perspectives 11 May 2020; 1 (1): 12912. doi: https://doi.org/10.1525/gp.2020.12912. (C) 2020 by the Regents of the University of California. Copying and permissions notice: Authorization to copy this content beyond fair use (as specified in Sections 107 and 108 of the U. S. Copyright Law) for internal or personal use, or the internal or personal use of specific clients, is granted by the Regents of the University of California for libraries and other users, provided that they are registered with and pay the specified fee via Rightslink $₫$ or directly with the Copyright Clearance Center. 


\title{
Communication and Media
}

\section{Datafication and the Welfare State}

\author{
Lina Dencik ${ }^{1}$, Anne Kaun² b \\ ${ }^{1}$ Cardiff University, United Kingdom , 2 Södertörn University, Sweden
}

Keywords: data justice, data inequalities, datafiction, welfare state

https://doi.org/10.1525/gp.2020.12912

\section{Global Perspectives}

Vol. 1, Issue 1, 2020

Both vehemently protected and attacked in equal measure, the welfare state as an idea and as a policy agenda remains as relevant as ever. It refers not only to a program of social welfare and the provision of social services, but also to a model of the state and the economy. According to Offe (1984), the welfare state in advanced capitalist economies is a formula that consists of the explicit obligation of the state apparatus to provide assistance and support to those citizens who suffer from specific needs and risks characteristic of the market society, and it is based on a recognition of the formal role of labor unions in both collective bargaining and the formation of public policy. Although actively dismantled in recent decades as globalization and neoliberalism have taken hold of much of the modern world-system, its future continues to be fought over. It serves as a model for society that is seen to privilege a commitment to decommodification, universal access, and social solidarity as a way to overcome the most prominent contradictions of capitalism. A product of the twinned global crises of the Great Depression and the Second World War, the modern welfare state therefore encapsulates a moment of political and economic settlement, a mechanism of stabilization that arguably could emerge only out of such crises.

From the outset, technology, particularly information and communication technologies, has played a key role in the development of the welfare state (Hobsbawm 1994). It has been instrumental in the creation of bureaucracies and forms of population management that have long been central to the way the welfare state is administered. Gunnar and Alva Myrdal, for example, famously argued for social engineering based on statistics and the use of technology to solve the population crisis of Sweden in the 1930s and 1940s. Their suggestions are now considered central to the ideas and cornerstones of the Nordic welfare state model (Kananen 2014). The creation of databases and the monitoring of citizens was from early on a fundamental part of assessing population needs and determining allocation of resources, a type of surveillance that has been the subject of much critique for creating categories of "deserving" and "undeserving" citizens (Offe 1984). At the same time, the advent of digitization has also been seen as a challenge to the welfare state and its ability to deliver on its promises, disrupting labor relations, undermining social security, and changing the parameters of state governance. With growing trends such as mass data collection, automation, and artificial intelligence, these tensions have only intensified, putting the welfare state into further question (Petropoulos et al. 2019).
At the time of writing this introduction, the question of not only the future of the welfare state but also how technology intersects with it has gained new pertinence as we find ourselves in the midst of another global crisis. The global pandemic brought about by the rapid spread of COVID-19 has put social welfare questions and the role of the state at the top of the agenda once more. The crisis is seen to have prompted a return of the Leviathan state, a social contract with an absolute sovereign in which the state provides the ultimate insurance against an intolerable human condition (Mishra 2020), and it has provided renewed impetus for demands for universal health care, stable employment, and a basic income (Standing 2020). Certainly, initial responses to the pandemic and ongoing lockdowns across the world have aligned around state interventions in the economy not seen in a generation, with governments designing various packages of increased public spending, which has (re)invited a rhetoric of the importance of economic planning and strong social security.

Technology is proving to be at the heart of this crisis and how the welfare state might emerge from it. As "social distancing" speeds up the transition to social and economic life online, often presented as a seamless process, Big Tech has quickly (in partnership with governments) established itself as our (new) infrastructure for everything from health to education to work (Bharthur 2020). At the same time, Big Tech is also presented as a solution to the crisis through extensive data collection, contact tracing, and certification. At the time of writing, the big data analytics company Palantir is in talks with a number of governments, including those of the United Kingdom, Germany, and France, to provide data infrastructure for health services during the pandemic, and Google and Apple have announced a joint venture to develop infrastructure for contact-tracing apps that determine if an individual has been in close proximity to someone COVID-19 positive (Fouquet and Torsoli 2020; Kelion 2020). Furthermore, the EU Commission has requested metadata from large mobile phone carriers, including German Telekom and Orange, to calculate mobility patterns and track the spread of the coronavirus across Europe (Scott, Cerulus, and Kayali 2020). It is claimed that only anonymized and aggregated data will be collected and that data will not be used to control or sanction lockdown measures but to use this data to be able to predict where medical supplies will be needed most.

These initiatives introduce new questions about the nature of surveillance in governance, the place of data protection frameworks such as the EU's General Data Protection 
Regulation (GDPR), and the role of private companies in the delivery of public services that all form an important part of the contemporary debate on technology and the welfare state. As Baker (2020, para. 13) puts it, "for governments looking to monitor their citizens even more closely, and companies looking to get rich by doing the same, it would be hard to imagine a more perfect crisis than a global pandemic." Moreover, the turn to data and the reliance on data-driven systems in governance introduces key epistemological and ontological assumptions about what constitutes relevant social knowledge for decision-making and how individuals and populations should be understood and managed. Data, on this premise, needs to be collected in as large a quantity as possible (total information capture), processed through automation, with the view to calculate all possible outcomes-a knowing of all risks-so as to preempt them before they occur (Andrejevic 2019). While a global crisis like the one we are currently in might present itself as a state of exception in these terms, the trend of datafication across social life is one that was already firmly in place.

What does it mean to organize the welfare state around this trend of datafication? With this special issue, we take stock of this question and explore the multiple ways in which the practices, values, and logics that underpin the advancement of datafication intersect with the practices, values, and logics that form the basis of the public services that we commonly associate with the modern welfare state. The idea for this special issue emerged out of discussions in the Nordic research network Datafication, Data Inequalities and Data Justice, of which we are both members. It is perhaps no surprise that it is a Nordic context that spurred on the engagement with the welfare state as this has long been a central feature of Nordic societies, both as an idea and in practice. However, the question of how datafication impacts public services, particularly in relation to social welfare, is a global one and one that cannot be universalized, whether in terms of data-driven developments or their implications (Milan and Treré 2019). At the same time, the history of the modern welfare state is one that has most frequently been associated with Europe in what Judt (2007) has described as the "social-democratic moment" of the postwar period. This history is reflected in our contributions that predominantly engage with European and Western settings, while doing so in the context of globalization. Many of the issues discussed in our contributions are being raised elsewhere as technology infrastructures globalize and standardize practices (cf. Booth 2019).

\section{CONTEXTUALIZING THE DIGITAL WELFARE STATE}

The "digital welfare state" is rapidly becoming a prominent marker for developments in governance around the world. In 2019 the UN Special Rapporteur for extreme poverty and human rights submitted a report on uses of digital technologies in the welfare state to the UN General Assembly. The report notes that "the digital welfare state is either already a reality or is emerging in many countries across the globe." In it he argues that "systems of social protection and assistance are increasingly driven by digital data and technologies that are used to automate, predict, identify, surveil, detect, target and punish" (Alston 2019, 1). Seeing this as part of a "digital transformation," the report highlights how technologies are applied to and emerge out of established practices, such as identity verification, eligibility assessments, benefit calculations and payments, fraud prevention and detection, risk scoring and need classification, and communication between welfare authorities and bene- ficiaries. Not all of these relate to the collection and algorithmic processing of data, as is the focus of this special issue; some are rooted in earlier digitization projects. There have, for example, been policy-led attempts to improve state-citizen relations with the help of digital infrastructures through so-called e-governance initiatives (Chadwick 2006; Chadwick and May 2003; Dawes 2008; Lember, Kattel, and Tõnurist 2018; Torres, Pina, and Acerete 2006). Recent technological developments, however, have initiated a new kind of digitization in the welfare sector. With these, we see public administration increasingly working with data collection and algorithms to take autonomous decisions and administrate more efficiently, but also-it is argued-more fairly without human interference and flaws (Veale and Brass 2019). Yeung (2018a, 2018b) sees this growing reliance on data-driven systems and algorithmic processing as a paradigm shift in public administration toward what she terms "new public analytics," one in which these technologies take on regulatory functions and establish themselves as a new regime in the provision of public services and social welfare (Eubanks 2018).

This paradigm shift emerges out of long-standing transformations in the welfare state and public administration. Large-scale economic crises since the early 1970s have led to a shift in how welfare provision in Western democracies is organized (Bleses and Seeleib-Kaiser 2004; Bonoli and Natali 2012; Gilbert 2002; Hemerijck 2011). In what is often referred to as a dismantling or a transformation of the welfare state, a number of governments have privatized specific public services-including education, child, and health care as well as the corrections and the media sectors-and since the 1980s have increasingly introduced strategies of new public management to run welfare sector organizations with the objective of making them more efficient by implementing private sector management routines (Pollitt, van Thiel, and Homburg 2007). Moreover, the emergence of the welfare state was from the outset a class compromise, a political solution to conflict that emerged out of a "matrix of social power" (Offe 1984) between collective actors, most notably the state, industry, labor unions, and civil society. The composition of this matrix has significantly changed over the last few decades, with the financialization of the economy, establishment of global supply chains, growth of precarious work, inequality, and decline in union membership, particularly in the Global North. These developments have altered the role of the state and the demands put on it in relation to citizens (Harvey 2011).

With this special issue, we see how datafication and algorithmic automation are part of the transformation of the welfare state (Kuhlmann and Wollmann 2019; Pollitt and Bouckaert 2011). The articles explore what we see as a shift toward a new regime in public services and welfare provision intricately linked to digital infrastructures that results in new forms of control and support. While the collection and aggregation of information emerges out of longerstanding developments of "modernization" and "rationalization" in public administration, the growing datafication of social life is integrating specific data practices into these settings (White et al. 2009; Pasquale 2019). In part, these practices refer to increased data sharing between different bodies and actors, but they also refer to new ways decisions might be made and assessments of population needs and risks conducted. Such practices raise questions about how the meaning and conduct of professional expertise is changing and about the kinds of policy approaches that might be supported or undermined by these developments. It does so particularly as public services increasingly mi- 
grate online, even to the extent of policy becoming "digital by default" as in the case of the Universal Credit system in the United Kingdom. Concerns here point to the way such a transition increases conditionality in social protection along with new forms of surveillance that, according to Alston (2020, para. 1), risk leading to a "complete reversal of the traditional notion that the state should be accountable to the individual."

New forms of privatization are also part of these shifts-for example, those taking shape in the form of new actors, like technology companies entering the field of public administration that do not necessarily share the values that are part of the professional identity of civil servants. In many cases, public administration institutions are considered an important intermediary between the state and citizens (DuGay 2005; Lawton 2005; Maesschalck 2004; Van der Wal, De Graaf, and Lasthuizen 2008). Changes in the manner in which these institutions are organized have consequences for the relationship between the state and citizens as well as for democracy. Many of these consequences are premised on how the relationships between citizens and state institutions are changing, but also in terms of shifts in trust that citizens have in public-sector and state institutions and the place of accountability when decision-making is shaped by algorithms and autonomous systems. In that sense, automated decision-making affects public values that are deeply entrenched in understandings of democracy. Citizens, at the same time, have very little or no choice when it comes to the technical infrastructures that underlie public administration. They are, like users of other digital infrastructures, largely excluded from technological development at the level of governance and the design process, which limits their possibilities to deliberate on values encoded in the digital infrastructures as well as digital culture at large (Gillespie 2018).

We therefore argue that we need to understand the turn to datafication in the context of the welfare state as a form of policy intervention. Indeed, in the case of the UK's Universal Credit system, data-driven automation is articulated by the Department of Works and Pensions seemingly as the policy objective. ${ }^{1}$ The implementation of data-driven systems in public services is not simply a matter of efficiency or a quantitative shift: more information, shared faster. Rather, it extends and transforms dimensions of the welfare state that are qualitative in nature and that need to be understood in historical context. Datafication therefore needs to be treated as a political development rather than as a technological one, and one that sets out methods of knowing and definitions of social life that have implications for what values, logics, and forms of responses are privileged over others (Berry 2011; Boyd and Crawford 2012; Redden 2015). The digital welfare state is, in this sense, subject to "politicisation through technology" (Alston 2019) that is in need of critical interrogation and public deliberation.

\section{DATA COLLECTION, AUTOMATED DECISION-} MAKING, AND PROFILING

In this context of the emerging regime of algorithmic public services, the contributions to this special issue evolve around questions of data collection, automated decision- making, and profiling. These different aspects are clearly deeply interlinked, but we distinguish between them here to highlight the composition of the digital welfare state as it is approached in the collection of papers.

The ability to generate and aggregate large datasets has been an important aspect of changes in public administration. Often this development is associated with more data collection and data sharing, providing more granular information about populations and individuals, through the creation of "data lakes" or "data warehouses" across areas such as health care, social services, and police (Dencik et al. 2019). This data collection and sharing, in turn, enable automation of spheres of social activity and organization, including the welfare sector and communication with citizens, that have previously been difficult to automate by introducing algorithms and artificial intelligence (Shestakofsky 2017; Thewissen and Rueda 2019). Yet the nature of this data and how it is collected, aggregated and shared is rarely properly scrutinized. As we see clearly in the contribution from Ustek-Spilda and Alastalo, datasets come to define populations and those who are included and excluded in the welfare state. In their analysis of how asylum seekers are included in population registers in Norway and Finland, we see how statistics compilations are constructed in a way that has political outcomes. In this sense, welfare policies are made at the point of sorting, categorizing, and ordering data, before it is fed into further software or other administrative devices of government. In the contribution from Nikunen, meanwhile, data collection carried out by public service media as a key pillar of the welfare state is interrogated, exploring the implications this practice has for dependencies on commercial platforms. In the push toward datafication, public service media becomes embedded within a platformed media environment in which they have little control and find themselves in tension with dominant social media logics that potentially run counter to their value system. A focus on data collection, in this context, brings to light how values of egalitarianism and universalism associated with public service in the welfare state are challenged by the architecture of contemporary platform infrastructures.

A further key aspect of the digital welfare state is the way in which the collection of data is algorithmically processed for the purposes of automated decision-making. This refers to the activity of implementing and delegating tasks and decisions to both rule- and knowledge-based systems (Sumpter 2018). It encompasses automated decision-making and decision support systems that are used to automatically execute decisions to perform an action (Spielkamp 2018). With the help of mathematical models, big data, or the combination of different registers, algorithms issue a decision-for example, on an application for social benefits. Algorithms that are currently used in the welfare sector include simple decision trees (in Sweden, for example, the socalled Trelleborg model, which has automated decisions on social benefit applications [Velkova and Kaun 2019]); sorting (for example, the sorting algorithm developed by the Austrian Employment Services that automatically sorts applicants into three different categories [Kayser-Bril 2019]); and matching as well as predictive algorithms (for example, a predictive score estimating the likelihood of child abuse 
in Denmark [Alfter 2018]). In the contribution from Mann in this special issue, the case of the controversial RoboDebt in Australia is analyzed, an automated debt-raising program to identify "overpayment" of welfare benefits by using an algorithm to detect discrepancies between income reported to the welfare agency and that registered by the taxation office. In the article, Mann highlights the significance of nontechnological surveillance welfare and neoliberal welfare policies in shaping the implementation and use of RoboDebt. This sociopolitical context also has implications for how state-citizen relations might be conceived and engaged with. We see these developments around automated decision-making in welfare explored further in the contribution from Choroszewicz and Mäihäniemi, who provide a sociolegal analysis of the use of automated decision-making systems across six European countries. While we have standard data protection regulation in place across Europe in the form of the GDPR, their article highlights the varied approaches taken to automated decision-making in different national contexts. This points to the heterogeneous data practices emerging between countries that with their contrasting histories also shape the advancement of the digital welfare state differently. Some, for example, rely on mutual trust between public administration and citizens in the use of automated decision-making, whereas others are more explicit in the parameters of data use in ways that both protect and restrict citizens' rights.

Related to automated decision-making, a controversial aspect of the digital welfare state is the potential of profiling. While this has previously been associated with the more pathological ends of criminology and psychiatry, the creation of profiles has migrated into the mainstream along with the rise of surveillance technologies (Bernard 2019). It is now increasingly common to rely on data about aspects of behavior, including preferences and inferred emotions, to create profiles about people across various aspects of social life, whether in job recruitment or insurance or dating (McStay 2018). In the context of welfare, we see versions of this trend in the form of "citizen scoring"-that is, a practice for making assessments and predictions about individuals or households based on data about characteristics and behaviors (Dencik et al. 2018). This may include, for example, the likelihood that someone will commit a crime (Angwin et al. 2016) or engage in benefit fraud (Lomas 2020). In the contribution by Zejnilovic et al. to this special issue, aspects of this profiling are discussed in relation to the assessment of individuals' risk of becoming long-term unemployed in Portugal. In their study, they particularly focus on the complexity surrounding the ways in which professionals working in the public employment service engage with data-driven risk assessments and process the categorization of individuals into different profiles as a way to support the assignment of interventions.

\section{IMPLICATIONS OF THE DATAFIED WELFARE STATE: BEYOND EFFICIENCY}

All the contributions to this issue convene around the political dimension of datafication in relation to the welfare state. Although technology is often described in neutral terms, the articles in this special issue show how the collection and use of data in the welfare context have implications for values of public administration beyond efficiency and service, including democracy, legal frameworks, objectivity, freedom of expression, and equality. In this way, they also point to the importance of adequate public debate, scrutiny, and deliberation dedicated to the integration of data infrastructures into public services, particularly in the area of welfare. Currently, we have very little of such debate and scrutiny as systems are frequently introduced as pilots, which then become normalized, or as part of technological upgrades seen to be devoid of policy implications (Alston 2019). Many organizations, including within the public sector, feel pressured to turn to data systems as a way to modernize and advance as part of a rhetoric around the revolutionary potentials of data analytics (Beer 2019). Often it is also argued that algorithms free civil servants from repetitive and monotonous tasks (Engin and Treleaven 2019).

However, as illustrated by the articles in this special issue, data-driven systems do not work without friction (Zarsky 2015). Zejnilovic et al., for example, point out the different obligations that face counselors working in public employment services that sometimes conflict with the kind of risk profiles generated by algorithmic systems. At the same time, while professionals might find working with data-driven risk assessments a negative experience that means risk scores are effectively ignored, they paradoxically show a preference for having the system in place to satisfy a perceived need to engage with large volumes of data. In Sweden, when Trelleborg municipality started to fully automate the decision-making process for social benefits and reduce the number of caseworkers, other municipalities planning to implement similar models were confronted with strikes and caseworkers leaving their jobs based on a reluctance toward automation and concerns about the implications of automated decision-making for the relationship with applicants for social benefits (Björklund 2018).

Ustek-Spilda and Alastalo, meanwhile, point to another area of friction in relation to how data is produced that actively marginalizes complex circumstances and lived experiences. In their analysis of population registers, they highlight how not receiving a personal identification number means that certain individuals are not considered as part of the official population, with concrete implications in everyday life including the inability to sign contracts and open bank accounts. This case study highlights the continued segregation of deserving and undeserving citizens as a key feature of the welfare state, now enacted through data and automation, questioning any assertion of the welfare state as a guarantor of citizenship and justice both historically and now. What is more, their study speaks to the necessarily reductionist nature of data that can be managed and sorted as abstractions without a clear understanding of the embodied power relations and social effects produced by those activities (Monahan 2008). This reductionism and abstraction, as our collection of articles point out, is also important for understanding the different biases, absences, and errors that are not just prominent but features of algorithmic public services. Data-driven systems are dependent on historical practices of who or what is counted and what is not, the "quality" of data input, and the nature of algorithmic design, which determines what is weighted and how much. All of these stages of datafication can lead to forms of data harms, such as exclusion, discrimination, and predatory inclusion (Redden and Brand 2018; Barocas and Selbst 2016; Seamster and Charron-Chénier 2017). In the case of RoboDebt, as discussed in Mann's contribution, for example, a mismatching of inaccurate data resulted in around 20-40 percent of the debts being false, a rate that meant that vulnerable and already financially disadvantaged individuals were being issued with debts that they did not owe.

Eubanks (2018), in her well-known study of the US welfare sector, argues that automated decision-making can worsen poverty and long-established inequalities. Rather 
than overcoming constraints of time and resources that the public sector is faced with, automation has been part of a reduction in services. Similarly, as Zejnilovic et al. point out in their contribution, public services in Europe are implementing algorithmic governance and datafication spurred on by budget cuts and austerity programs following the financial crisis of 2008. This austerity agenda provides an important context for the ways in which predictive analytics and practices of citizen scoring are situated in relation to welfare provision and the punitive measures that emerge (Dencik et al. 2019).

Moreover, implications of datafication for the democratic process as a feature of the welfare state are discussed throughout the collection of articles in different ways. State-citizen relations in democracies often rely, in theory at least, on some ability to scrutinize and challenge decisions made about individuals. In relation to automated decision-making, issues of explainability and accountability are prominent challenges when tasks are delegated to complex algorithmic systems (Ananny 2016; Sandvig et al. 2016). In the GDPR, protections are in place precisely to try and meet these challenges, but it is still not clear how such protections can be adequately implemented, not least because of the complexity surrounding human agency in relation to sociotechnical systems (Kitchin 2017; Velkova and Kaun 2019). Questions of democratic process take on further pertinence in light of the intricate ecosystems between public and private entities taking shape through technological infrastructures in the public sector. Nikunen, in her contribution, illustrates the dependencies on commercial platforms that are a key feature of datafication and that risk displacing public bodies. Increasingly, we see the way in which public services are organizing themselves around the disruptive activities of technology companies that over time come to dictate societal arrangements (Andrejevic 2019).

This development is significant beyond a question of privatization because it also entails a form of power that is able to define and shape policy and the meaning of social welfare. By attributing risk factors to individual behaviors and characteristics, for example, the turn to data-driven systems might shift the responsibility of social ills onto individuals, privileging individualized over collective responses and responsibilities. That is, over time, these systems, in their emphasis on correlation over causation, can individualize social problems by directing attention away from structural causes (Keddell 2015). As systems optimized for capturing personalized risk, they therefore appear as contradictory to values of social solidarity or of social mobility. Instead, driven by an imperative of preemption, automation can create a form of social stasis, one in which citizens are no longer granted the freedom to define their own future but remain in predefined categories set by data points. Al- though it is important to recognize that such freedom never really existed for all or even for most citizens, also at the apogee of the welfare state, we might still want to reflect on what such power means even for the ideal of what the modern welfare state entails. As the encroachment of technology companies into the public sector rapidly expands under the current pandemic, such reflection has never been more important. While the welfare state emerged at the verge of crisis, the health crisis and the related economic downturn we are now in opens up a moment to rearticulate the role and importance of organizing welfare based on solidarity, universal access, and equality.

\section{ACKNOWLEDGMENTS}

Lina Dencik receives funding from an ERC Starting Grant (grant no. 759903), and Anne Kaun receives funding from the Kone Foundation (Project Algorithmic Cultures, PI: Minna Ruckenstein). We are grateful to the Nordic research network Datafication, Data Inequalities, and Data Justice (funded by the joint committee for Nordic research councils in the humanities and social sciences NOS-HS) and to Payal Arora and Liba Hladik at Global Perspectives for help with conceiving and executing this special issue.

\section{AUTHOR BIOGRAPHIES}

Lina Dencik is reader in the School of Journalism, Media and Culture at Cardiff University, in the United Kingdom, and co-founder of the Data Justice Lab. She has published widely on digital media, resistance, and the politics of data and is currently principal investigator of the DATAJUSTICE project, funded by an ERC Starting Grant. Her most recent publications include Digital Citizenship in a Datafied Society (with Arne Hintz and Karin Wahl-Jorgensen, Polity, 2018) and The Media Manifesto (with Natalie Fenton, Des Freedman, and Justin Schlosberg, Polity, 2020).

Anne Kaun is associate professor in Media and Communication Studies at Södertörn University, in Sweden. Her research interests include algorithmic culture, data-based automation in the public sector, and the political implications of artificial intelligence. She is currently directing the Swedish Network on Automated Decision-Making in the Public Sector and is co-director of the Nordic Network for Datafication, Data Inequality and Data Justice. In 2016 she published her book Crisis and Critique: A Brief History of Media Participation (Zed Books); her book Making Time in Digital Lives is forthcoming (with Christine Lohmeier and Christian Pentzold, Rowman \& Littlefield, 2020). 


\section{REFERENCES}

Alfter, B. 2018. “Denmark.” In Automating Society: Taking Stock of Automated Decision-Making in the $E U$, edited by M. Spielkamp. https://algorithmwatch.o rg/wp-content/uploads/2019/01/Automating_Societ y_Report_2019.pdf.

Alston, P. 2019. "Report of the Special Rapporteur on Extreme Poverty and Human Rights.” A/74/48037. htt ps://www.ohchr.org/EN/NewsEvents/Pages/DisplayNe ws.aspx?NewsID=25156.

- - . 2020. "What the 'Digital Welfare State' Really Means for Human Rights.” OpenGlobalRights. http s://www.openglobalrights.org/digital-welfare-state-a nd-what-it-means-for-human-rights/.

Ananny, Mike. 2016. “Toward an Ethics of Algorithms: Convening, Observation, Probability, and Timeliness." Science, Technology, \& Human Values 41 (1): 93-117. https://doi.org/10.1177/016224391560 $\underline{6523}$.

Andrejevic, Mark. 2019. Automated Media. New York: Routledge. https://doi.org/10.4324/9780429242595.

Angwin, J., J. Larson, S. Mattu, and L. Kirchner. 2016. “Machine Bias." ProPublica. May 23, 2016. https://ww w.propublica.org/article/machine-bias-risk-assessme nts-in-criminal-sentencing.

Baker, P.C. 2020. “'We Can’t Go Back to Normal': How Will Coronavirus Change the World?" Guardian, March 31, 2020. https://www.theguardian.com/world/ 2020/mar/31/how-will-the-world-emerge-from-the-c oronavirus-crisis.

Barocas, Solon, and Andrew D. Selbst. 2016. “Big Data's Disparate Impact.” SSRN Electronic Journal. ht tps://doi.org/10.2139/ssrn.2477899.

Beer, D. 2019. The Data Gaze. London: Sage.

Bernard, A. 2019. The Triumph of Profiling: The Self in Digital Culture. Cambridge: Polity Press.

Berry, D. 2011. “The Computational Turn: Thinking about the Digital Humanities." Culture Machine 12: $1-22$.

Bharthur, D. 2020. “The Valley and the Virus.” Bot Populi. April. April 3, 2020. https://botpopuli.net/bigtech-covid19-corona-silicon-valley.
Björklund, M. 2018. “Socialsekretärare Slutar i Protest När Robot Hanterar Ansökningar” [Civil Servants Leave in Protest When Robot Is Handling Applications.” Dagens Nyheter, January 21, 2018.

Bleses, P., and M. Seeleib-Kaiser. 2004. The Dual Transformation of the German Welfare State. Basingstoke, UK: Palgrave Macmillan.

Bonoli, Giuliano, and David Natali. 2012. "The Politics of the New Welfare State: Analysing Reforms in Western Europe." In The Politics of the New Welfare State, edited by Giuliano Bonoli and David Natali, 3-20. Oxford: Oxford University Press. http s://doi.org/10.1093/acprof:oso/9780199645244.001.00 01.

Booth, R. 2019. "Automating Poverty.” Guardian. 2019. https://www.theguardian.com/technology/serie s/automating-poverty.

Boyd, Danah, and Kate Crawford. 2012. "Critical Questions for Big Data.” Information,

Communication \& Society 15 (5): 662-79. https://do i.org/10.1080/1369118x.2012.678878.

Chadwick, Andrew. 2006. Internet Politics: States Citizens, and New Communication Technologies. New York: Oxford University Press.

Chadwick, Andrew, and Christopher May. 2003. "Interaction between States and Citizens in the Age of the Internet: 'E-Government' in the United States, Britain, and the European Union.” Governance 16 (2): 271-300. https://doi.org/10.1111/1468-0491.00216.

Dawes, Sharon S. 2008. "The Evolution and Continuing Challenges of E-Governance.” Public Administration Review 68 (October): S86-102. http s://doi.org/10.1111/j.1540-6210.2008.00981.x.

Dencik, Lina, Arne Hintz, Joanna Redden, and Harry Warne. 2018. "Data Scores as Governance: Investigating Uses of Citizen Scoring in Public Services.” Project Report. Cardiff University. https://d atajustice.files.wordpress.com/2018/12/data-scores-a s-governance-project-report2.pdf.

Dencik, Lina, Joanna Redden, Arne Hintz, and Harry Warne. 2019. “The 'Golden View': Data-Driven Governance in the Scoring Society.” Internet Policy Review 8 (2). https://doi.org/10.14763/2019.2.1413.

DuGay, P. 2005. The Values of Bureaucracy. Oxford: Oxford University Press. 
Engin, Zeynep, and Philip Treleaven. 2019.

"Algorithmic Government: Automating Public Services and Supporting Civil Servants in Using Data Science Technologies.” The Computer Journal 62 (3): 448-60. https://doi.org/10.1093/comjnl/bxy082.

Eubanks, V. 2018. Automating Inequality: How HighTech Tools Profile, Police, and Punish the Poor. New York: St. Martin's Press.

Fouquet, H., and A. Torsoli. 2020. "Palantir in Talks with Germany, France for Virus-Fighting Tool.” Bloomberg, April 1, 2020. https://www.bloomberg.co m/news/articles/2020-04-01/palantir-in-talks-with-g ermany-france-for-virus-fighting-tool.

Gilbert, N. 2002. Transformation of the Welfare State: The Silent Surrender of Public Responsibility. Oxford: Oxford University Press.

Gillespie, T. 2018. Custodians of the Internet: Platforms, Content Moderation, and Hidden Decisions That Shape Social Media. New Haven, CT: Yale University Press.

Harvey, D. 2011. The Enigma of Capital. London: Profile Books.

Hemerijck, Anton. 2011. "Two or Three Waves of Welfare State Transformation?” In Towards A Social Investment Welfare State? Ideas, Policies and Challenges, edited by N Morel, B. Palier, and J. Palme, 33-60. Bristol, UK: Policy Press. https://doi.org/10.13 32/policypress/9781847429247.003.0002.

Hobsbawm, E. 1994. The Age of Extremes: 1914-1991. London: Abacus.

Judt, T. 2007. PostWar: A History of Europe Since 1945. London: Pimlico.

Kananen, J. 2014. The Nordic Welfare State in Three Eras: From Emancipation to Discipline. Farnham, UK: Ashgate.

Kayser-Bril, N. 2019. Austria's Employment Agency Rolls out Discriminatory Algorithm, Sees No Problem. Berlin: AlgorithmWatch. https://algorithmwatch.org/ en/story/austrias-employment-agency-ams-rolls-outdiscriminatory-algorithm.

Keddell, Emily. 2015. “The Ethics of Predictive Risk Modelling in the Aotearoa/New Zealand Child Welfare Context: Child Abuse Prevention or Neo-Liberal Tool?” Critical Social Policy 35 (1): 69-88. https://do i.org/10.1177/0261018314543224.

Kelion, L. 2020. "Coronavirus: Apple and Google Team Up to Contact Trace Covid-19.” BBC News, April 10, 2020. https://www.bbc.co.uk/news/technology-52 246319.
Kitchin, Rob. 2017. “Thinking Critically about and Researching Algorithms.” Information, Communication \& Society 20 (1): 14-29. https://doi.o rg/10.1080/1369118x.2016.1154087.

Kuhlmann, S., and H. Wollmann. 2019. Introduction to Comparative Public Administration:

Administrative Systems and Reforms in Europe. Cheltenham, UK: Edward Elgar.

Lawton, Alan. 2005. "Public Service Ethics in a Changing World.” Futures 37 (2-3): 231-43. https://d oi.org/10.1016/i.futures.2004.03.029.

Lember, Veiko, Rainer Kattel, and Piret Tõnurist. 2018. "Technological Capacity in the Public Sector: The Case of Estonia." International Review of Administrative Sciences 84 (2): 214-30. https://doi.or $\mathrm{g} / 10.1177 / 0020852317735164$.

Lomas, N. 2020. "Blackbox Welfare Fraud Detection System Breaches Human Rights, Dutch Court Rules.” Techcrunch, February, February 6, 2020. https://techc runch.com/2020/02/06/blackbox-welfare-fraud-detect ion-system-breaches-human-rights-dutch-court-rule s/.

Maesschalck, Jeroen. 2004. “The Impact of New Public Management Reforms on Public Servants' Ethics: Towards a Theory.” Public Administration 82 (2): 465-89. https://doi.org/10.1111/i.0033-3298.200 4.00403.X.

McStay, A. 2018. Emotional AI: The Rise of Empathic Media. London: Sage.

Milan, Stefania, and Emiliano Treré. 2019. "Big Data from the South(s): Beyond Data Universalism.” Television \& New Media 20 (4): 319-35. https://doi.or $\mathrm{g} / 10.1177 / 1527476419837739$.

Mishra, P. 2020. "Coronavirus Will Revive an AllPowerful State.” Bloomberg, March 17, 2020. http s://www.bloomberg.com/opinion/articles/2020-03-1 7/coronavirus-will-revive-an-all-powerful-state.

Monahan, Torin. 2008. "Surveillance and Inequality.” Surveillance \& Society 5 (3): 217-26. https://doi.org/1 0.24908/ss.v5i3.3421.

Offe, C. 1984. "Some Contradictions of the Modern Welfare State.” In Claus Offe: Contradictions of the Welfare State, edited by J. Keane, 147-61. London: Hutchinson.

Pasquale, Frank. 2019. "Professional Judgment in an Era of Artificial Intelligence and Machine Learning.” Boundary 246 (1): 73-101. https://doi.org/10.1215/01 903659-7271351. 
Petropoulos, G., J. Marcus, N. Moës, and E.

Bergamini. 2019. Digitalisation and European Welfare States. Brussels: Bruegel.

Pollitt, C., and G. Bouckaert. 2011. Public

Management Reform. Oxford: Oxford University Press.

Pollitt, C., S. van Thiel, and V. Homburg. 2007. New Public Management in Europe. Basingstoke, UK: Palgrave Macmillan.

Redden, J. 2015. “Big Data as System of Knowledge: Investigating Canadian Governance.” In Compromised Data: From Social Media to Big Data, edited by G. Elmer, G. Langlois, and J. Redden, 17-39. London: Bloomsbury.

Redden, J., and J. Brand. 2018. Data Harm Record. Cardiff University. https://datajusticelab.org/data-har m-record/.

Sandvig, C., K. Hamilton, K. Karahalios, and C. Langbort. 2016. "When the Algorithm Itself Is a Racist: Diagnosing Ethical Harm in the Basic Components of Software." International Journal of Communication 10: 4972-90.

Scott, M., L. Cerulus, and L. Kayali. 2020.

"Commission Tells Carriers to Hand Over Mobile Data in Coronavirus Fight.” Politico, March 25, 2020. http s://www.politico.eu/article/european-commission-mo bile-phone-data-thierry-breton-coronavirus-covid1 9/.

Seamster, Louise, and Raphaël Charron-Chénier. 2017. "Predatory Inclusion and Education Debt: Rethinking the Racial Wealth Gap.” Social Currents 4 (3): 199-207. https://doi.org/10.1177/2329496516686 $\underline{620}$.

Shestakofsky, Benjamin. 2017. "Working Algorithms: Software Automation and the Future of Work." Work and Occupations 44 (4): 376-423. https://doi.org/10.1 177/0730888417726119.

Spielkamp, M. 2018. “Automating Society: Taking Stock of Automated Decision-Making in the EU.” Berlin: AlgorithmWatch. https://algorithmwatch.org/ wp-content/uploads/2019/02/Automating_Society_Re port_2019.pdf.

Standing, G. 2020. "Coronavirus Has Shown Us Why We Urgently Need to Make a Basic Income a Reality.” World Economic Forum. April 13, 2020. https://ww w.weforum.org/agenda/2020/04/coronavirus-made-ba sic-income-vital/.
Sumpter, D. 2018. Outnumbered: From Facebook and Google to Fake News and Filter-Bubbles-The Algorithms That Control Our Lives. London: Bloomsbury.

Thewissen, Stefan, and David Rueda. 2019. "Automation and the Welfare State: Technological Change as a Determinant of Redistribution Preferences.” Comparative Political Studies 52 (2): 171-208. https://doi.org/10.1177/0010414017740600.

Torres, LOURDES, VICENTE Pina, and BASILIO Acerete. 2006. "E-Governance Developments in European Union Cities: Reshaping Government's Relationship with Citizens.” Governance 19 (2): 277-302. https://doi.org/10.1111/j.1468-0491.2006.00 315.x.

Van der Wal, Zeger, Gjalt De Graaf, and Karin Lasthuizen. 2008. "What's Valued Most? Similarities and Differences between the Organisational Values of the Public and the Private Sector." Public Administration 86 (2): 465-82. https://doi.org/10.111 1/j.1467-9299.2008.00719.x.

Veale, Michael, and Irina Brass. 2019. “Administration by Algorithm? Public Management Meets Public Sector Machine Learning." In Algorithmic Regulation, edited by K. Yeung and M. Lodge, 121-49. Oxford: Oxford University Press.

Velkova, Julia, and Anne Kaun. 2019. “Algorithmic Resistance: Media Practices and the Politics of Repair.” Information, Communication \& Society, August, 1-18. https://doi.org/10.1080/1369118x.201 9.1657162 .

White, Sue, Karen Broadhurst, David Wastell, Sue Peckover, Chris Hall, and Andy Pithouse. 2009. "Whither Practice-near Research in the Modernization Programme? Policy Blunders in Children's Services." Journal of Social Work Practice 23 (4): 401-11. https://doi.org/10.1080/026505309033 $\underline{74945}$.

Yeung, Karen. 2018a. "Algorithmic Government: Towards a New Public Analytics?” Paper Presented at Ethical and Social Challenges Posed by Artificial Intelligence, Cumberland Lodge, Windsor, UK.

---. 2018b. “Algorithmic Regulation: A Critical Interrogation.” Regulation \& Governance 12 (4): 505-23. https://doi.org/10.1111/rego.12158.

Zarsky, Tal. 2015. "The Trouble with Algorithmic Decisions: An Analytic Road Map to Examine Efficiency and Fairness in Automated and Opaque Decision Making.” Science, Technology, \& Human Values 41 (1): 118-32. https://doi.org/10.1177/016224 $\underline{3915605575 .}$. 